\title{
Ethnopolitogenesis of Ancient Egyptian and Mesopotamian Ethnic Groups
}

\author{
Rubin Gatufovich Saifullin ${ }^{1}$ \\ ${ }^{1}$ Kazan Federal University, Russia \\ Correspondence: Rubin Gatufovich Saifullin, Kazan Federal University, Kremlin street, 18, 420008, Kazan, \\ Tatarstan Republic, Russia. E-mail: saifrubin@mail.ru
}

Received: October 6, 2014 Accepted: November 14, 2014 Online Published: February 12, 2015

doi:10.5539/ass.v11n5p158

URL: http://dx.doi.org/10.5539/ass.v11n5p158

\begin{abstract}
The main provisions of the biosocial approach to the study of the polity dynamics in its conflict aspect are formulated in this article. Its essence consists in the assertion of the dependence of the polity dynamics on the population quality. The L. N. Gumilev concept, which explores this dependence, is considered, and its short comings are opened in this paper. On the basis of this concept the universal, invariant with respect to ethnic groups, types of polities and eras law - numerical algorithm of ethnopolitogenesis is formulated. Ethnopolitogenesis of Egyptian and ancient Mesopotamian (Sumerians, Babylonians, Assyrians and others) ethnic groups is analyzed in order to verify the numerical algorithm. The conclusion that it developed as a whole in accordance with a numerical algorithm is formulated.
\end{abstract}

Keywords: biosocial approach, the numerical algorithm of ethnopolitogenesis, ethnopolitogenesis of Egyptian and ancient Mesopotamian ethnic groups

\section{Introduction}

The political history of many countries developed in cycles, from prosperity and stability to the crisis and decline, and then to the next prosperity. There are different approaches to the explanation of this recurrence. Among them, one of the priorities is the approach that links the political dynamics of agrarian states with socio-demographic cycles (see, for example: Goldstone, 1991; Turchin, 2003). The authors of these works see the main causes of the crisis in the impact of quantitative factors: overproduction of elites and peasants overpopulation, that lead to the intensification of the struggle for resources and civil war among the elite, as well as the dispossession of peasants, hunger and riots. In this case, the impact of the population quality dynamics on the conflict political dynamics remains outside the scope.

The necessity of taking account of the population quality follows from the fact that "the most important condition for the regulation of the population size is heterogeneity of its constituent individuals" (Gilyarov, 1990, p. 49). The quality dynamics is one of the most effective mechanisms for population homeostasis by increasing the proportion of individuals of certain types when the population density is high (Dol'nik, 2009). Using the notions of L. N. Gumilev concept, these types in human populations can be called movers, sub movers and harmonious people (a detailed description of these types, see: Saifullin, 2014).

In this concept, the main subject of macro historical process, considered as an indivisible unity and interaction of ethnogenesis and policy genesis, is ethnicity as biosocial and social and natural phenomenon. One of the biological hypostasis of ethnicity manifests in the existence of passionate, sub passionate and harmonious types. The ratio of shares of these types determines the amount of ethnicity passionate energy, which determines its activity and success.

According to L. N. Gumilev, the dynamics of the relative proportions of different types (the dynamics of passionarity) defines the process of ethno genesis, which refers to the process of passing all stages of ethnicity development (phases of ethnogenesis) and phase transitions which divide them - crisis periods, which are characterized by large-scale internal conflicts, leading to weakening and sometimes decay and death of the statecreated by the ethnicity (Gumilev, 1994). Using the term "ethnopolitogenesis" (Turchin, 2003, p. 54), which was proposed by P. V. Turchin, we can say that the dynamics of passionarity determines the process of ethnopolitogenesis. 


\section{Method}

Given by L. N. Gumilev characteristics of each phase and the phase transition, the determination of the approximate age range of each phase and the approximate dating of the so-called "passionate impulse" that led to the formation of new ethnic groups, enabled him to inspect this concept by analyzing the ethnogenesis of these ethnic groups (Gumilev, 1994). However, its results cannot be considered conclusive. Different ethnic groups differ significantly in their age range in the same phases, no phase transitions are highlighted. It must be noted that L. N. Gumilev was unable to prove the existence of universal pattern, which describes the dynamics of the energy type shares as part of an ethnic group. This necessitated the introduction of the change concept.

As a result of these changes, the author's concept, based on the biosocial approach, was formed and its main provisions are as follows (for details on these positions see: Saifullin, 2014).

I. The main subject of macro historical process, which is indivisible unity and interaction of ethnogenesis and policy genesis, is ethnicity, which is regarded as biosocial and socio-natural phenomenon.

II. The success of the polity depends on the level of passionarity of the ethnic group, which created it, that is on the proportion of movers and sub movers in its composition.

III. At the heart of the passionarity phenomenon is the phenomenon of heterosis: moversare born in mixed marriages in racial-anthropological terms.

IV. Ethnicity in its development goes through a series of age-phases - stable periods and phase transitions which separate them - unstable periods of crisis.

V. Age ranges of ethnogenesis phases and phase transitions, as well as periods of crisis in some phases, similar in character to phase transitions are determined by universal, invariant with respect to historical periods and types of polities regularity - numerical algorithm of ethnopolitogenesis.

1. Elevation phase: 0 - 340-360 years. Consists of the following periods: incubation ( 0 - 100-155 years), explicit (100-155 - 340-360 years) and vague in the middle of the expansion phase (185-235 years) (denoted as 1a). The explicit period begins with the creation of a state by an ethnic group at the age of 100-155.

2. Phase transition of akmathic rise: $340-360$ - 450-470 years.

3. Akmathic phase: 450-470 - 630-655 years.

A troubled period of passionarity overheat is identified within this phase (540-560 - 570-585 years).

4. Akmathic breakdown transition phase: 630-655 - 680-725 years.

5. Breakage: $680-725$ - 755-810 years.

6. Phase transition for breakdown inertia: 755-810 - 840-875 years.

7. Inertia phase: $840-875$ - 1302-1334 years.

There are three crisis periods within this phase: the first $-7 \mathrm{a}(880-920-935-970$ years), the second $-7 \mathrm{~b}$ (1025-1070 - 1100-1145) and the third - 7c (1175-1215, 1260-1285) separated by four stable periods.

8. Inertia-obscuration transition phase: $1302-1334$ - about 1500 years.

VI. Troubles (with the violent nature of large-scale domestic conflicts), as well as major military defeats which are mainly a characteristic of unstable periods.

VII. The passionarity dynamics is synchronized by solar-climatic cycles, in particular, by 82 -year-old harmonica of Gleissberg cycle. This synchronization is manifested in the existence of "reproductive" ethnicity age, multiple of the number $82(902,1066,1230,1394$, and 1558 years), in which in the part of its isolated populations many movers are born, and that the relatively high proportion of moversare born during the 82 -year cycle. The year, which accounts for reproductive age, is, as a rule, in the middle of this cycle.

VIII. A great amount of movers is born in one of the reproductive ages, and they form new sub ethnicities, forming the core of "subsidiary" ethnic group. The year, which accounts for this age, is the starting point of child ethnicity ethno and social genesis.

IX. Several successively alternating in a particular area of an ethnic group, interconnected by the continuity of anthropological and racial type, language and culture, form hyperethnicity.

$X$. The first ethnicity of the hyper ethnicity is formed as a result of mixture of substrates that are different inracially anthropological terms. The passionate tension (the ratio of the passionarity number to the number of individuals that make up the ethnic group) of each of the following ethnic group is reduced due to the increasing 
racial and anthropological homogeneity of its population. As a rule, the third ethnic group in one of the first three unstable states is conquered by more passionate members of other tribes and does not restore its state independence.

The aim of this study is to verify the numerical algorithm on the example of the political history of ancient Egypt analysis, as well as the political history of the states that existed in ancient Mesopotamia - Akkadian and Sumerian-Akkadian kingdoms, Babylon, Assur and Assyrian power. The analysis must show that the unrest, as well as major military defeats occurred mostly during periods of unstable states of ancient Egyptian ethnic groups, as well as the Sumerians, Akkadians, and other ethnic groups that made up the population ofancient Mesopotamian states. To achieve the objective of the study it is necessary to determine the time of occurrence of each of these ethnic groups, and to consider their political history as to its numerical algorithm.

\section{Results and Discussion}

\subsection{Results of the Review Ethnopolitogenesis Egyptian-1 and Egyptian-2 and Discussion of These Results}

The emergence of the first lower and upper Egyptian ethnicities (Egyptian-1) marked the end of the formation of the dominant complex in their anthropological and racial characteristics, which remained throughout the existence of the Egyptian hyper ethnicity. Also, it was associated with the emergence of the ancient Egyptian language. According to V. P. Alekseev, anthropological continuity in Egypt is preserved up to the present, at least since the era of the IV millennium BC (Alekseev, 1986, p. 56). M. A. Korostovtsev dates the time of existence of the first stage of writing ancient Egyptian language development - the so-called old Egyptian language to XXXII-XXII centuries BC (Korostovtsev, 1963). On the basis of this anthropological and linguistic evidence one can suggest that the initial point of reference for the Egyptian-1 - it is about the middle of the IV millennium BC.

According to the numerical algorithm, ethnicity forms its polity at the age of 100-155, after which it begins territorial expansion. You can determine the approximate time frame of initial points of Egyptian ethnic groups, if you know when they formed their own states. However, this problem can be solved only for the Egyptians-3. The fact that the establishment of absolute chronological dates of the events of ancient Egyptian history is an extremely difficult task. There are various approaches to solving them (see, for example, Bickerman, 1968; Beckerath, 1997; Hornung et al., 2006). One can find differences in the chronology of more than 100 years in works of different authors. The earliest of the absolutely exact dates can be regarded as 664 BC - Assyrian invasion of Egypt.

The second half of the expansion phase of the Egyptians-3 accounts for reign of XXVI (Sais) dynasty that revived Egypt. Starting an explicit period of this phase can be associated with the strengthening of the ruler of Sais Tefnakht, the founder of XXIV dynasty that came to power around $740 \mathrm{BC}$ and in $727 \mathrm{BC}$ declared himself pharaoh (Ladynin, 2008, p. 146). If we assume that the founder of the state of the Egyptians is Tefnakht-3, we find that their initial reference point is between 840 and 895 years BC $(740+100-155$ years $=840-895)$.

To define the starting point of reference frame better we are relying on the position that the date of occurrence of all existing and currently existing ethnic groups should be separated by time duration, a multiple of 82 or 41 . It follows from the following reasoning. According to the currently prevailing view all non-African populations are the result of the divergence of a single ancestral population, migrated from Africa about 80 thousand years ago. Based on the hypothesis on passionate dynamics synchronization by the 82-year-old harmonica of Gleissberg cycle, one might think that child group hive off from this community occurred in the reproductive age of the ancestral community. All subsequent hive-off also occurred in the reproductive ages. The date of the formation of new ethnic groups as a result of mixing anthropologically different substrates can be separated by time durations that are multiples of the number 41 (half of the cycle). This implies that the date of occurrence of all ethnic groups should be separated by time duration, a multiple of 82 or 41 .

L. N. Gumilev describes the approximate date of occurrence of a number of ethnic groups - about 8 BC (Gumilev, 1993, p. 195). In our opinion, it is necessary to date the reference point of ethnopolitogenesis of these ethnic groups by $9 \mathrm{BC}$. Based on that date, and on the proposition that the initial starting point of all ethnic groups are separated by time duration, a multiple of 82 or 41 , we can define the reference point of the Egyptians-3 is 870 BC 870 and 9 years BC separates the year 861. This number is a multiple of $41(861: 41=$ 21). The assumption that the starting point of the Egyptian-1 dates from about the middle of the IV millennium $\mathrm{BC}$ it follows that it is in $3494 \mathrm{BC}$. The analysis of ethnopolitogenesis of Egyptians-2 allows dating their starting point in 2428 BC. The Egyptians-2 branched off in the reproductive age of the Egyptian-1in 1066 (3494 - 2428 $=1066)$, the Egyptians-3 - in the reproductive age of the Egyptians-2 in $1558(2428-870=1558)$. 
Now we can write the ethnopolitogenesis formula of Egyptian hyper ethnos:

\section{Egyptians-1 - $3494 \Rightarrow 1066$ Egyptians-2 - $2428 \Rightarrow 1558$ Egyptians-3 - $911 \leftrightarrow 870$}

All dating is BC. Bold text denotes the initial point of reference frame of ethnopolitogenesis. To the right of the arrows reproductive age is indicated, in which there was a hive off of child ethnos from the mother's ethnic group. Double arrow $(\leftrightarrow)$ indicates that the initial point of reference frame of the Egyptians-3 repeatedly shifted from $870 \mathrm{BC} 911 \mathrm{BC}$ and back (for more details see below).

To perform the second paragraph of the research program (distemper, as well as major military defeats occurred mostly during periods of unstable states) we need to know the exact dates of unrest and military defeats that occurred in the history of ancient Egypt. However, as mentioned above, the conventional chronology of ancient Egyptian history IV-II millennium BC does not exist. When analyzing the ethnopolitogenesis of Egyptians-1 and the initial phases of the Egyptians-2 ethnopolitogenesis, we are using the chronology J. von Beckerath, the dating of who have average values in comparison with the dating of other researchers. The accuracy of dating, determined by J. von Beckerath for the reign of Egyptian kings and dynasties III millennium BC, ranges within 50 years. We are using later dates.

For the dating of the New Kingdom J. von Beckerath uses so-called "short" history, that causes reasonable criticism of the Russian researchers I. A. Ladynin and A. A. Nemirovsky, claiming that it is preferable to use the "average" history (Ladynin, Nemirovsky, 1997). For the New Kingdom, we will use the dating of I. A. Ladynin (Ladynin, 2008; Ladynin et al., 2010).

Let's compute in which ethnic ages of Egyptians-1 and 2 turmoil occurred and Egypt suffered a major military defeat. Then we are defining, in what period there were turmoil and defeats. The results are presented in Table 1. With a question mark the presumable character of distemper is indicated, as well as alleged age limits of certain periods. In the second column, next to the ethnic ages of the ancient Egyptian ethnic nationalities in parentheses the period numeration is specified in accordance with the above numerical algorithm: elevation phase- 1 , troubled period of mid-expansion phase - 1a, the phase transition of akmathic elevation - 2, etc. Ethnic age attributable to the steady period, and the numbering of this period are shown in italics in Table 1 and other tables. All dates listed in the table are BC.

Table 1. Time of Troubles and major military defeats in ethnopolitogenesis of Egyptians-1 and 2

\# The chronological framework of distemper and / or major military defeats

1 The rebellion in Lower Egypt during the reign of Khasekhemwy (2684-2657), which led to the civil war.

2 The popular uprising (?) in about 2454, which put an end to the rule of Dynasty IV.

3 I Transition period (VII-X Dynasty: in about 2166-2020) - Time of unrest and anarchy, Libyan attacks.

4

Flash of internecine struggle in the reign of Mentuhotep IV (in about 1983-1976 years) (Ladynin, 2008, p. 91).

5 II Transition period (XIII-XVII dynasty: in about 1793-1550) - The time of popular uprisings, frequent change of rulers, the conquest of Egypt by the Hyksos in about 1645.

6 Riots in Upper Egypt during the reign of Ahmose I (about 1550-1525 (Beckerath, 1997)). The intensification of the struggle between the military and serving and nome and priestly aristocracy during the reign of Akhenaten (1365-1348). Religious and political reform.

7 Unsuccessful war with Mitanni in about 1360, the loss of possessions in Syria. Unsuccessful war with the Hittites during the reign of Ay (1338-1334), the loss of all the Egyptian possessions in the Eastern Mediterranean (Ladynin, 2008, p. 118-125).

The usurpation of the throne by Amenmessein about 1213. Rebellion of Irsuin about 1195. The

8 termination of the troubles by Setnakht (1192-1190), the founder of the XX dynasty (Ladynin et al., 2010, p. 48).

Civil War in about 1093 between the high priest of Amun - Amenhotep and the viceroy of

9 Nubia - Pinehessy during the reign of Ramesses XI (Stuchevsky, 1983). The collapse of Egypt after the death of Ramesses XI in about 1075, the beginning of the III transition period. The libyan rule in Egypt in the X-VIII centuries.

* Here and below is the ethnic age of Egyptians-2.
Age of

Egyptians-1 and 2 (years)

810-837 (6)

1040 (7б)

1328-1474 (8)

262-350?* (1)

350-408 (2)

445-452 (2)

635-680? (4)

680-760? (5)

760-875? (6)

890-895? (7)

1063-1094 (7b)

$1215-1236(7 \mathrm{c})$

$1335-1600(8)$ 
Let's discuss the results. Of the 9 cases of unrest and major military defeats 6 occurred during the periods of unstable states of ancient Egyptian ethnic groups. There are three anomalies: parts I and II of the transition period occurred, respectively, in the expansion phase and the fracture of the Egyptians-2; rebellions in the reign of Ahmose I took place at the beginning of the inertia phase. Let's explain these anomalies.

The second half of the elevation phase of the Egyptians-2 coincided with the inertia-obscuration transition phase of Egyptians-1. This phase transition is a period of ethnic group agony, when it is replaced with child ethnicity. It is characterized by permanent turmoil, the invasion of foreigners, the expansion of the state of child ethnicity or "barbarian" state, seeking to destroy the agonizing state of maternal ethnic group. These symptoms were typical for I and III transitional periods of ancient Egyptian history. The main reason for fracture of the New Kingdom statehood can be regarded as the end of the inertia phase and the beginning of the inertia-obscuration transition phase of the Egyptians-2.

The era of the New Kingdom, when Egypt was an empire (Kuzishchin, 1999, p. 30) occurred in the inertia phase of the Egyptian-2. According to L. N. Gumilev, this phase is characterized by "territorial expansion, the creation of grand empires and vast colonies" (Gumilev, 1994, p. 314). All these features were characteristics of the New Kingdom. The ethnicity state reaches the peak of its power also during the phase of akmathic that occurred at Egyptian-2 in the reign of the XII dynasty that ruled in the 1976-1794 period BC (Beckerath, 1997), which corresponds to the age range of this phase $(2428-1976-1794=452-634)$.

During the II Transitional period successful attempts to restore central authority in Egypt were undertaken. They are associated with the names of Neferhotep I (Ladynin, 2008, p. 102) and his successors - Sebekhotep IV and Sobekhotep V. These pharaohs ruled, apparently, in the second half of the XVIII century BC, and the strengthening of the central government would be logical to associate with the beginning of the break phase, probably in 1740-s BC $(2428-1748=680$ years $)$. With the end of this phase and the onset of the phase transition for breakdown-inertia, probably, in the middle of the XVII century BC Egypt began to unravel, and it was conquered by the Hyksos.

The third anomaly is possibly due to incorrect dating of Ahmose I reign by J. von Beckerath. There is other dating. Thus, according to the American E. Wente, Ahmose reigned in 1570-1546 BC. Based, apparently, on the opinion of this researcher, I. A. Ladynin writes that Ahmose rules from the beginning of 1560 to the end of 1540s BC (Ladynin, 2008, p. 106). If we use the chronology of these authors, we find that the riots that took place around the middle of the reign of Ahmose, occurred at the end of the phase transition for breakdown-inertia $(2428-1558-1553=870-875$ years $)$.

\subsection{Results of the Review Ethnopolitogenesis Egyptian-3 and Discussion of These Results}

Before proceeding to the analysis of the Egyptians-3 ethnopolitogenesis, we are formulating some preliminary remarks. We can assume that the first two Egyptian ethnic it is are close to perfect as their ethnopolitogenesis developed almost in exact accordance with the numerical algorithm (ideal ethnic conditions: see (Saifullin, 2009). Egyptians-3 are among the ethnic groups who violated all the perfect conditions. From the $\mathrm{X}$ century to $\mathrm{BC}$ the ruling elite of Egypt, and apparently some of the common people began to be Libyans in VIII-VII centuries BCthe Cushits, in Ptolemaic Egypt - Greeks and Macedonians. Thus, the population of Egypt in I millennium BC was a super-ethnos, and, strictly speaking, confusion and, in particular, defeat in foreign wars could be due to stay in unstable states not only the Egyptians-3, but also other ethnic groups within the Egyptian superethnos. However, in order to reduce the complexity, we restrict our attention to Egyptians-3 ethnopolitogenesis, although such a review would mean a strong simplification of the real picture of the Egyptian superethnos ethnopolitogenesis.

In an ethnic group close to the ideal, the bigger part of movers, that forms new populations, is born in about the middle of the 82-year cycle, substantially smaller - at the beginning, the smallest - at the end of the cycle. This leads to the fact that large populations that form new ethnic it yare formed in the middle of the cycle (it's the first condition of ideality). In the real ethnic group the number of populations that occurred in the middle and the beginning of the cycle, is often roughly equal. Because of the epidemic, famine or war the number of populations that arose in the middle of the cycle may accidentally fall off a much greater number of populations that arose at the beginning, and the last will prevail. This may lead to displacement of the initial reference point to the beginning of the ethnopolitogenesis cycle. If an approximately equal number of populations that arose in the early and mid-cycle, maintains throughout the life of the ethnic group, it leads to a periodic shift of the initial reference point from the middle to the beginning of the cycle and back, which was characteristic of the Egyptian-3. Their starting point repeatedly shifted from $870 \mathrm{BC}$ to $911 \mathrm{BC}$ and vice versa. For example, the first such shift occurred, probably in about $730 \mathrm{BC}$. 
We are computing in which Egyptians-3 ethnic ages occurred turmoil and Egypt suffered major military defeats, and determine the period of turmoil and destruction. The results are presented in Table 2.

Table 2. Time of Troubles and major military defeats in Egyptians-3 ethnopolitogenesis

\begin{tabular}{|c|c|c|}
\hline \# & The chronological framework of confusion and / or major military defeats & $\begin{array}{l}\text { Egyptians-3* } \\
\text { age (years) }\end{array}$ \\
\hline 1 & $\begin{array}{l}\text { The invasion of Egypt by napat Pharaoh Piye in } 726 \text { AD. The conquest of Egypt by } \\
\text { Shabak in } 715 \text { (Beckerath, 1997). The dominion of the Kushite Dynasty XXV and the } \\
\text { Assyrians in Egypt. Dodecarchy in 671-656. The XXVI Sais dynasty, which united Egypt, } \\
\text { comes to power in } 656 \text {. }\end{array}$ & $\begin{array}{l}185-235(1 \mathrm{a}) \\
235-255(1) \\
\mathbf{1 9 9 - 2 1 4}(1 \mathrm{a})\end{array}$ \\
\hline 2 & $\begin{array}{l}\text { Civil War between Apries and Ahmose II in } 570-567 \text {. The invasion of the Babylonians in } \\
\text { Egypt in 568-567. The conquest of Egypt by the Persians in } 525 \text { BC, a failed uprising } \\
\text { against the Persian power in } 486-484 \text { and } 460-454 \text {. }\end{array}$ & $341-457(2)$ \\
\hline 3 & $\begin{array}{l}\text { The revolt against Teos in 361, its overthrow. The conquest of Egypt by the Persians in } \\
342 \text { BC. The entry of Alexander the Great troops in } 332 \text {. }\end{array}$ & $550-579(3 a)$ \\
\hline 4 & $\begin{array}{l}\text { The uprising in Egypt in } 244 \text { and 217-186. The defeat of the Egyptian armies of Antiochus } \\
\text { IV and his invasion of Egypt in 170. Dionysius Petosarapis Revolt in 165-164. }\end{array}$ & $\begin{array}{l}667-725(4) \\
741-747(5) \\
700-706(4)\end{array}$ \\
\hline 5 & The riots in The bait in $88-85$ and Thinis nome in 49 . & $823-860(6)$ \\
\hline 6 & Bukolas Revolt in $172 * *$. & $1083(7 b)$ \\
\hline 7 & The uprising in Egypt in 295-297. & $1206-1208(7 \mathrm{c})$ \\
\hline
\end{tabular}

* The Egyptians-3 age is indicated for the initial point of reference in $911 \mathrm{BC}$

** Here in after referred dating is AD.

The third crisis of the inertial phase moved, apparently, to the inertia-obscuration transition phase. Further political history of Egypt is related to Egyptians-4 and Egyptian-5 ethnopolitogenesis. The Consideration of ethnopolitogenesis of these ethnic groups is beyond the scope of this paper.

Let's discuss the results. Of the 7 cases of unrest and major military defeats 5 occurred in periods of unstable states of the Egyptians-3. There are two anomalies: dodecarchy period (simultaneous reign of twelve kings) in 671-656 years BC came in the second half of the elevation phase, and the period associated with the defeat of the Egyptians by Antiochus IV and Dionysius Petosarapis revolt fell to the break age. Let's explain these anomalies.

Probably shortly before the beginning of these periods (respectively, about 680 and $180 \mathrm{BC}$ ) the starting point shifted from 911 to $870 \mathrm{BC}$. We are calculating the age limits of dodecarchy for the starting point $870 \mathrm{BC}$. The result is $199-214$ years $(870-671-656=199-214)$, which fits into the framework of vague period of the middle elevation phase. The age range of the crisis period 170-164 years BC for this starting is 700-706 years, which fits into the framework of the akmathic-breakdown transition phase. In the table, these age limits are indicated in bold.

The offsetting of the starting point from 911 to 870 BC was, apparently, in the early 520-s BC. With this assumption, the age range of the first Persian rule (525-404 BC) is 345-466, that fit into the framework of the phase transition of akmathic elevation. The success of the Amyrtaeus uprising in $404 \mathrm{BC}$, which resulted in the overthrown of the Persian rule, helped to start akmathic phase about this year.

As it often happens with the third ethnic group, after the second conquest of Egypt by the Persians during the passionate heat, Egyptians-3 never recovered their independence.

\subsection{Results of the Review Ethnopolitogenesis Ancient Mesopotamian Ethnic Groups and Discussion of These Results}

Let's analyze the ancient Mesopotamian ethnic group ethno and police genesis. We are defining the initial point of reference constituted the main population of Lower Mesopotamia south Akkad (Akkad and Babylon) and Sumerian ethnic groups and also the Amorites, the Kassites and the Chaldeans that formed the ruling elite and some of the population. In this case, we are using the so-called "middle chronology", according to which the beginning of the reign of Sargon and the birth of Akkad kingdom is determined in 2316 BC (Nemirovsky, 2008, p. 205).

According to the numerical algorithm, ethnicity forms its polity at the age of 100-155, after which it begins territorial expansion. We assume that ethnic groups that were the components of the lower Mesopotamian 
superethnos created their own state at this age. Although this assumption may not be true. Ethnicity in this age can create a chiefdom, which may turn into an early state only at the beginning of one of the stable periods.

If we assume that the Akkadian kingdom was established at the age of south Akkadians 100-155, we find that their initial reference point is between 2416 and $2471 \mathrm{BC}(2316+100-155=2416-2471)$. The two dates - 2469 and $2428 \mathrm{BC}$ satisfy the condition that the date of occurrence of all ethnic groups are divided by time duration of multiples of the number 82 or 41 .

The increased proportion of movers (they form a new population of the ethnic group) is born during the 82-year solar-climate cycle. For the south Akkadians ethnic group this cycle is as follows: 2510-2469-2428 BC. For this ethnic group, as well as for the Egyptians-3, the first ideal condition is not fulfilled. The south Akkadians starting point, probably shifted at the beginning of the expansion phase from the middle to the end of the cycle that is from 2469 to $2428 \mathrm{BC}$.

The movers of subsidiary south Akkadian ethnic group that detached themselves at the reproductive age of maternal ethnicity of 1558 years, were born during the next 82-year cycle: 952-911-870 BC. The initial starting point of this ethnic group returned to the middle of the cycle - to $911 \mathrm{BC}$.

This child ethnicity is the third ethnic group. The third ethnic group in one of the first three unstable states is usually won by passionate foreigners who form its ruling elite. In $539 \mathrm{BC}$ Babylonia was conquered by the Persians and never restored its independence. The crisis period preceded the conquest after the death of Nebuchadnezzar II in 562 BC. It was characterized by overthrow and assassination of kings (Nemirovsky, 2008, p. 327-328). The crisis was associated with the beginning of the phase transition of akmathic elevation (911 $562=349$ years). Thus, the southAkkadians- 3 were conquered during this phase transition.

It is known that in the beginning of II millennium BC Sumerian was a dead language. This means that at this time, the process of assimilation of the Sumerians by Akkadians finished. The third ethnicity is usually assimilated by passionate foreigners. This suggests that in the II millennium BC there was a third Sumerian ethnicity (Sumerians-3), who formed their own state (the Sealand kingdom) in $1722 \mathrm{BC}$ in the south of Lower Mesopotamia. This kingdom was conquered by Babylon in 1460 BC (Nemirovsky, 2008, p. 180) during the phase transition of akmathic elevation.

Assuming that the Sealand kingdomwas created by the Sumerians-3 at the age of 100-155, we determined that their initial reference point is between 1822 and $1877 \mathrm{BC}(1722+100-155=1822-1877) .1854 \mathrm{BC}$ is separated from the other dates of the ethnic groups emergence in the periods, a multiple of 82 or 41 . For example, 1854 and $2469 \mathrm{BC}$ are separated by 615 years. The number 615 is divisible by $41(615: 41=15)$.

The Sumerian-2 ethno and police genesis analysis provides a basis to date their initial point of reference - 3084 BC. It is not possible to define the starting point of the Sumerians-1 because of the lack of evidence. Perhaps it is in $4150 \mathrm{BC}$.

It is known that Babylon was the capital of the Amorite tribe Amnanu. The beginning of the Babylon I (Amorite) dynasty reign dates back to $1895 \mathrm{BC}$ (Nemirovsky, 2008, p. 218). We determine that the initial starting point of the Amorites-Amnanu is in the range between 1995 and $2050 \mathrm{BC}(1895+100-155=1955-2050)$. We find that it falls on 2018 BC. 2018 and 1854 BC separate 164 years. The number 164 is divisible by $41(164: 41=4)$.

In $1595 \mathrm{BC}$ Babylonia was conquered by the Kassites. Kassites invaded Mesopotamia, led by their leader Gandash in 1742 BC (Nemirovsky, 2008, p. 229). Shortly before the expansion, they formed, apparently, their chiefdom. We can determine that the initial point of the Kassites reference is between 1842 and 1897 BC (1742 $+100-155=1842-1897)$. We find that in the middle of this period there is the next date for the initial reference point of Kassites ethno and police genesis analysis - is $1854 \mathrm{BC}$.

There is no accurate data on the formation time of the Chaldean principalities in south Marshlands. They were formed, probably about mid-X century BC. If this is correct, the reference point of the Chaldean ethno and police genesis analysis can be dated to $1075 \mathrm{BC}$.

According to the ancient period of the history of the nome state Assur the chronology is inaccurate, making it difficult to determine the initial points of reference of north Acadian ethnic groups. The analysis of their ethno and police genesis gives reason to believe that in Upper Mesopotamia two ethnic groups arose, which we conventionally call Assur (his starting point - it's 2223 BC) and Assyrian (his starting point - it is 1854 BC). About $1700 \mathrm{BC}$ as a result of the troubles Adasi became the ruler of Assur, whose descendants ruled in Assur in the next century (Nemirovsky, 2008, p. 285). If we assume that the first Assyrian ruler Adasi, that means he came to power at the age of the Assyrians - about 154 years $(1854-1700=154)$. 
Table 3. Troubles and military defeat in ethnopolitogenesis of lower Mesopotamian ethnicities

\begin{tabular}{|c|c|c|c|c|c|}
\hline \multirow[t]{2}{*}{ \# } & \multirow{2}{*}{$\begin{array}{l}\text { The chronological framework of the troubles } \\
\text { and / or major military defeats }\end{array}$} & \multicolumn{4}{|c|}{ Ethnic group age (years) } \\
\hline & & $\begin{array}{l}\text { Sumerians- } \\
2 \text { and } 3\end{array}$ & SA-2 и 3 & А и $\mathrm{Ch}$ & K \\
\hline 1 & $\begin{array}{l}\text { The popular uprising in Lagash, the Urukagina coming to power } \\
\text { in approx. } 2318 .\end{array}$ & $766(6)$ & & & \\
\hline 2 & $\begin{array}{l}\text { The conquest of Sumer by Sargon approx. in 2312. Rebellion in } \\
\text { Sumer approx. in } 2261 \text { (Nemirovsky, 2008, p. 205). }\end{array}$ & $772,823(6)$ & & & \\
\hline 3 & $\begin{array}{l}\text { Rebellion in Sumer during the reign of Sargon's successors. } \\
\text { Uprising in Sumer and Akkad approx. in } 2236 .\end{array}$ & $823-848(6)$ & $192(1 \mathrm{a})$ & & \\
\hline 4 & The conquest of Akkad by Gutians approx. in 2175 . & $909(7 \mathrm{a})$ & $253(1)$ & & \\
\hline 5 & $\begin{array}{l}\text { The overthrow of Gutians approx. in } 2109 \text {. The Ur III coming to } \\
\text { power. }\end{array}$ & $975(7 a)$ & $319(1)$ & & \\
\hline 6 & $\begin{array}{l}\text { The beginning of Amorites intrusion approx. in 2025. The defeat } \\
\text { of the Sumerian-Akkadian kingdom by Elamites approx. in } 2003 \\
\text { (Nemirovsky, 2008, p. 212). }\end{array}$ & $\begin{array}{l}1059-1081 \\
(7 b)\end{array}$ & $403-425(2)$ & & \\
\hline 7 & $\begin{array}{l}\text { The defeat of Isin by Amorite kingdom Larsa in } 1898 \text {, the loss of } \\
\text { the south territories. The conquest of Isin by Larsa in } 1794 \text {. }\end{array}$ & $\begin{array}{c}1186(7 \mathrm{c}) \\
1290(7)\end{array}$ & $\begin{array}{l}530(3) \\
634(4)\end{array}$ & & \\
\hline 8 & The conquest by Hammurabi throughout Mesopotamia in 1755 . & $1329(8)$ & $673(4)$ & $263(1)$ & \\
\hline 9 & $\begin{array}{l}\text { The invasion of the Kassites in 1742. The rebellion in Sumer in } \\
1741-1737 \text { and in Akkad in } 1736 .\end{array}$ & $\begin{array}{c}1343-1347 \\
(8)\end{array}$ & $692(4)$ & $\begin{array}{l}276-282 \\
\text { (1) }\end{array}$ & $\begin{array}{l}112 \\
(1)\end{array}$ \\
\hline 10 & $\begin{array}{l}\text { The capture of Babylon by the Hittites in } 1595 \text {, the struggle } \\
\text { between the Sealand kingdom and the Kassites for supremacy. } \\
\text { The adoption of the Kassite dynasty in Babylon (Nemirovsky, } \\
\text { 2008, p. 231). }\end{array}$ & $259 *(1)$ & $833(6)$ & $423(2)$ & $\begin{array}{r}259 \\
(1)\end{array}$ \\
\hline 11 & $\begin{array}{l}\text { The annexation of the Seaside kingdom by Babylon approx. in } \\
1460 .\end{array}$ & $394(2)$ & $968(7 ?)$ & $\begin{array}{l}558 \\
(3 ?)\end{array}$ & $\begin{array}{r}394 \\
(2)\end{array}$ \\
\hline 12 & $\begin{array}{l}\text { The rebellion of the Amorites and Babylon approx. in } 1400 \text {. } \\
\text { Expulsion of the Amorites from the country (Nemirovsky, } 2008 \text {, } \\
\text { p. 234-235). }\end{array}$ & $454(3)$ & $1028(7 b)$ & $\begin{array}{l}618 \\
(3)\end{array}$ & $\begin{array}{r}454 \\
(3)\end{array}$ \\
\hline 13 & $\begin{array}{l}\text { The conquest of Babylon by the Assyrians approx. in } 1225 \\
\text { (Nemirovsky, 2008, p. 290) and the Elamite approx. in } 1160 .\end{array}$ & $\begin{array}{l}629-697 \\
(4)\end{array}$ & $\begin{array}{l}1203-1271 \\
\quad(7 \mathrm{c})\end{array}$ & & $\begin{array}{r}-697 \\
(4)\end{array}$ \\
\hline
\end{tabular}
Coming to power of III sin dynasty, which liberated the country from the Elamite domination.

14 The capture of Babylonia cities by the Assyrians in about 1090 (Nemirovsky, 2008, p. 294). The decline of Babylonia, the Aramean invasion in the mid of XI century.

15 The invasion of the Assyrians in Babylonia and Chaldea in 851-850. The payment of tribute to Chaldean principalities.

16 The invasion of the Assyrians in Babylonia in 813, the captivity of the Babylonian king (Sedov, 2004).

17 Troubles in Babylonia, the invasion of the Assyrians in 729, who defeated the Chaldeans (Nemirovsky, 2008, p. 306).

18 The invasion of the Assyrians in Babylonia in 703, 700, 693 and 689, the defeat of the Chaldeans (Nemirovsky, 2008, p. 310-311).

19 The uprising in Babylonia against the power of Assyria in 652-648. The defeat of Babylon.

20 The successful revolt in Babylonia against the Assyrian power in 626 BC. The birth of the new Babylonian (Chaldeans) dynasty.

21 The conquest of Babylon by the Persians in 539 BC.

22 The uprising in Babylonia against the power of the Persians in 522-521, 484 and 482.

\section{4-804 1338-1378 \\ (6) \\ (8)}

\begin{tabular}{ccc}
$1003-1004$ & $1577-1578$ & $224-225^{* *}$ \\
$(7)$ & $(8)$ & $(1 \mathrm{a})$ \\
$1041(76)$ & $1615(8)$ & $262(1)$ \\
& & \\
$1125(76 ?)$ & $182^{* * *}$ & 346 \\
$(1)$ & $(2)$ \\
$1151-1165$ & $208-222$ & $372-386(2)$ \\
$(7)$ & $(1 \mathrm{a})$ \\
$1202-1206$ & $257-263(1)$ & $423-427(2)$ \\
$(7 \mathrm{c})$ & & \\
$1228(7 \mathrm{c})$ & $285(1)$ & $449(3)$ \\
$1315(8)$ & $372(2)$ & $536(3)$ \\
$1332-1372$ & $389-429(2)$ & $553-554(3 \mathrm{a})$ \\
$(8)$ & & $591-593(3)$ \\
\hline
\end{tabular}

* Here in after the ethnic Sumerian-3 age is indicated.

** Here in after the ethnic Chaldeans age is indicated.

*** Here in after the ethnic south Akkaids- 3 age is indicated. 
First Akkadian ethnicity (Akkadians-1) consisted of two population groups - the north and south, formed, respectively, during the next 82-year cycles: 3453-3412-3371 and 3412-3371-3330 BC.

Now we can write the schemes of ethno and police genesis of Akkadian and Sumerian hyper ethnos:

$$
\begin{gathered}
\text { Assur - } 2223 \text { and Assyrians - } \mathbf{1 8 5 4} \rightarrow \text { death } \\
\text { 仓 } 1230 \gtrsim 1558
\end{gathered}
$$

Akkadians-1 - 3453-3412-3371-3330

$\sqrt{ } 902$

South Akkadians -2 - $2428 \Rightarrow 1558$ South Akkad.-3 - 911 $\leftarrow \quad \mathbf{8 7 0} \rightarrow$ death;

Sumerians- 1 - 4150? $\Rightarrow 1066$ Sumerians-2 - 3084 $\Rightarrow 1230$ Sumerians-3-1854 $\rightarrow$ death.

All dating is BC. Bold text denotes the initial point of reference of ethno and police genesis. To the right of the arrows reproductive age is indicated, in which there was the hiving off of the child ethnic group from the mother's ethnic group.

To perform the second paragraph of the research program (distemper, as well as major military defeats occurred mostly during periods of unstable states of Mesopotamian ethnic groups) we are calculating in which ethnic ages of these ethnic groups turmoil occurred, and Mesopotamian states suffered major military defeats. Then we are defining, in what period turmoil and defeats occurred. The results are presented separately for lower and upper Mesopotamian ethnic groups, respectively, in Tables 3 and 4.

The analysis of ethno and police genesis of lower Mesopotamian ethnic groups begins with a popular uprising in Lagash, that enthroned Urukagina (in about 2318-2312 BC) (Nemirovsky, 2008, p. 204) - one of the first events in the history of Mesopotamia, the chronology of which is considered to be probably relatively accurate. The abbreviation SA-2 and 3 is the southAkkadians, 2 and 3, A and $\mathrm{Ch}-$ the Amorites and the Chaldeans, K Kassites. The numeration of the period in accordance with numerical algorithm is shown in brackets next to the ethnic age. The question mark shows presumptive period. All dates listed in the table are BC.

Let's discuss the results. In all cases, the troubles in Lower Mesopotamia and the conquest of its territory took place in those periods when, at least, most of the ethnic groups inhabiting it were in an unstable state. So, Sumer was shaken by turmoil, and it was conquered by the Akkadians, when the Sumerians- 2 were in the phase transition for breakdown-inertia (cases 1-3). Sumerian-Akkadian kingdom was lost at a time when the Sumerians-2 were in the phase transition for breakdown inertia, and the south-Akkadians-2 were in the phase transition for akmathic elevation (case 6). Amorite dynasty fell in the period when the Amorites were in a phase transition of akmathic elevation and Akkadians-2 were in the phase transition for breakdown-inertia (case 10); the Kassite dynasty - at a time when the Sumerians-3 and Kassites were in the akmatika-breakdown transition phase, and the Akkadians-2 - in the third crisis of the inertia phase (case 13). Invasion of the Assyrians and the conquest of Babylon by the Persians took place when two of the three ethnic groups that made up the population of Lower Mesopotamia, were not in stable state (cases 15-19, 21).

On the contrary, the dynasties of lower Mesopotamia were at the top of their power in the periods when the ethnic groups inhabiting them were steady. Thus, III Dynasty of Ur came to power when the Sumerians- 2 came in the second period of inertia phase, and the Akkadians-2 were still in the elevation phase (case 5). II dynasty of Isin liberated the country from the rule of the Elamite, when the Sumerians-3 entered the break age, and the Akkadians-2 - in the final period of the inertia phase (case 13). Chaldean Nabopolassarre leased Babylon from Assyrian domination, when the Chaldeans entered the akmathic phase and Akkadians-3 were in the elevation phase (case 20).

There are no completely abnormal cases if one regards the cases when the troubles in Lower Mesopotamia and the conquest of the territory occurred in the periods in which at least the majority of ethnic groups inhabiting it were steady. But there are cases $(4,11-12)$, which may be considered, so to say, halfway abnormal. Let us examine them in more detail.

The Sargon power was conquered by Gutium in about 2175 BC, when the Sumerians- 2 entered the first crisis of inertia phase, but the Akkadians-2 were in the steady state of elevation phase. Two circumstances may have contributed to the conquest. The Sumerians were the majority of the population of the state, and their ethnopolitogenesis contributed decisively to the ethnopolitogenesis of the lower Mesopotamian superethnos. Among the south Akkadians were probably represented the populations that belonged to the first south Akkadian ethnic group, the starting point of which is 3371 BC. In 2175 this ethnic group was in an unstable state of the third crisis of inertia phase $(3371-2175=1196$ years $)$, that apparently moved into the inertia-obscuration transition phase. 
Kassite Babylonia annexed the Sealand kingdom approx. in 1460 BC, when the Kassites and coeval with them Sumerians-3 were in the middle of the akmathic elevation transition phase. The military success of the ethnic group that is in unstable state, is usually short-lived. Apparently, a significant part of the Babylonian army was the Akkadians and the Amorites, who were in stable states, respectively, in the second period of inertia and akmathic phases.

You can try to answer the question of why the struggle for supremacy in Babylon after the destruction of it by Hittites in 1595 BC it won the Kassites and not coeval with them Sumerians-3of the Sealand kingdom. Apparently, Kassites belonged to the second ethnic group, the passionate tension of which is higher than that of the third, to which the Sumerians belonged to.

Amorites revolted in about $1400 \mathrm{BC}$, but were defeated and driven out of Babylonia. As it is indicated in the table, the ethnic age of the Amorites of the amnanu tribe was 618 years in $1400 \mathrm{BC}$ and they were in the late akmathic phase. It is possible that these events occurred in about $1385 \mathrm{BC}$, when amnanu entered the akmatik-breakdown transition phase $(2018-1385=633$ years $)$. Also, there may be another explanation for this anomaly. As you know, several Amorite tribes lived in the territory of Babylonia (Nemirovsky, 2008, p. 216), the initial points of reference of ethnopolitogenesis, the parts of which could be different from the starting point of amnanu. For example, they can be dated to 2469 BC. The age of the Amorites was BC 1069 years $(2469-1400$ $=1069)$ in 1400 then, which corresponds to the second crisis of inertia phase.

In contrast to the south Akkadians, the ruling elite of the north ones was formed from their own ethnic environment. Other ethnic groups are usually the elite at the third ethnic group, which was typical of the population of Lower Mesopotamia, most of which were the akkadized Sumerians-3. The population of Upper Mesopotamia ethnic groups belonged to the second ethnic groups, the passionate tension of which is much higher. This explains the relatively high combat effectiveness of north Akkadians, especially the Assyrians.

We are computing in what ethnic ages of north Akkadian ethnicities (the Assuriansand the Assyrians) occurred distemper, and the state suffered major military defeats. Then we are defining in what period turmoil and defeats happened. The results are presented in Table 4.

Table 4. Troubles and major military defeats in ethnopolitogenesis of the Assurians and the Assyrians

\begin{tabular}{|c|c|c|c|}
\hline \multirow{2}{*}{ \# } & \multirow{2}{*}{$\begin{array}{l}\text { The chronological framework of the troubles } \\
\text { and / or major military defeats }\end{array}$} & \multicolumn{2}{|c|}{ Ethnic group age (years) } \\
\hline & & Assurians & Assyrians \\
\hline 1 & $\begin{array}{l}\text { The conquest of Assur by Shamshi-Adad in } 1810 \text { and Hammurabi in } 1757 \\
\text { (Nemirovsky, 2008, p. 222). }\end{array}$ & $413-466(2)$ & \\
\hline 2 & $\begin{array}{l}\text { The capture of Assur by Mitanni in the middle of the XV century } \\
\text { (Nemirovsky, 2008, p. 286). }\end{array}$ & $773(6)$ & $404(2)$ \\
\hline 3 & $\begin{array}{l}\text { The defeat of Assyria at the end of the reign (in 1198?) of Tukulti-Ninurta I } \\
\text { (1233-1197), his murder. Dynastic conflicts and turmoil in Assyria. The } \\
\text { invasion of Elamites approx. in 1135, the overthrow of the Assyrian king } \\
\text { Assur-dan I (Nemirovsky, 2008, pp. 291-292). }\end{array}$ & $\begin{array}{l}1025-1088 \\
(7 b)\end{array}$ & $656-699(4)$ \\
\hline 4 & $\begin{array}{l}\text { The loss of the power of Assyria under the successors of Tiglath-Pileser I } \\
\text { (1114-1076). The capture of almost all of Upper Mesopotamia by the } \\
\text { Arameans in approx. } 1000 \text {. Assyria is on the verge of death. The ending of } \\
\text { the troubled period with the Adad-nirari II (911-811) accession to the throne } \\
\text { (Nemirovsky, 2008, pp. 294-295, 300). }\end{array}$ & $\begin{array}{l}1147-1200 ? \\
(7) \\
1200-1312 \\
(7 \mathrm{c}-8)\end{array}$ & $\begin{array}{l}778-860 ?(6) \\
860-900 ?(7) \\
900-943(7 a)\end{array}$ \\
\hline 5 & $\begin{array}{l}\text { Civil War in } 827-822 \text {. Riots at the end of the reign of Adad-nirari III } \\
\text { (810-783). Civil War in } 763-758 \text { and } 746-745 \text {. Losses from Urartu. }\end{array}$ & & $\begin{array}{l}1027-1109 \\
\text { (7b) }\end{array}$ \\
\hline 6 & $\begin{array}{l}\text { Scythians offensive in to Assyria in 630-s. Ashurbanipal removal from power } \\
\text { of in approx. } 630 \text { Civil War in the Assyrian and Babylonian throne in } \\
627-623 \text {. Complete defeat and destruction of Assyria in 614-609 } \\
\text { (Nemirovsky, 2008, pp. 319-321). }\end{array}$ & & $\begin{array}{l}1224-1245 \\
\quad(7 c-8)\end{array}$ \\
\hline
\end{tabular}

Let's discuss the results. Almost in all cases of distemper in Assyria and the conquests of Assur, or Assyria lesions occurred only in those periods when the Assurians and the Assyrians were in unstable states. The only exception is the case 4. The loss of power of Assyria under the successors of Tiglath-Pileser I (from 1076 to about $1023 \mathrm{BC}$, if we assume that the Assurians entered the third crisis of inertia phase at the age of 1200 (2223 $-1200=1023)$ ) took place when the Assurians continued to be in the third period, the inertia phase. However, this anomaly is easily explained by the fact that the Assyrians at this time were in the breakdown-inertia phase transition $(1854-1076-1023=778-831)$. 
Another anomaly is that the Assyrians did not revive their power from the beginning of their inertia phase, probably in about $994 \mathrm{BC}(1854-860=994$ years $)$. This anomaly can be explained by the fact that during the first period of the inertia phase (from 994 to about $954 \mathrm{BC}$, if we assume that the Assyrians entered the first crisis of inertia phase at the age of 900 years $(1854-900=954))$ the Assurians were in the third crisis of the inertial phase $(2223-994-954=1229-1269$ years $)$. The third Assuriancrisis as well as the Assyrian moved into the inertia-obscuration transition phase that is the final period of the inertia phase of both ethnic groups did not take place.

\section{Conclusion}

The result of the study was the verification of the numerical algorithm on the example of the analysis of ancient Egyptian and ancient Mesopotamian ethnic groups ethnopolitogenesis. The analysis showed that the unrest and major military defeats occurred mainly during periods of unstable states of ancient Egyptian and lower Mesopotamian ethnic groups and almost exclusively during the periods of unstable states of northAkkadian ethnic groups. The anomalies are explained by the theory.

\section{References}

Alekseev, V. P. (1986). Ethnogenesis. Moscow: High School.

Beckerath, von J. (1997). Chronologie des pharaonischen Ägypten: Die Zeitbestimmung der ägyptischen Geschichte von der Vorzei bis 332 v. Chr., Mainz: Verlag Philipp von Zabern.

Bickerman, E. J. (1968). Chronology of the ancient world. Ithaca, New York, NY: Cornell University Press.

Dol'nik, V. R. (2009). Disobedient biosphere child. Conversations about human behavior in the company of birds, animals and children. St. Petersburg: Petroglyph publishing house.

Gilyarov, A. M. (1990). Population Ecology. Moscow: Issued by MSU.

Goldstone, J. A. (1991). Revolution and Rebellion in the Early Modern World. Berkeley: UCP.

Gumilev, L. N. (1993). Rhythms of Eurasia. In V. A. Michuryn (Eds.), Rhythms of Eurasia: the era and civilization (pp. 188-200). Moscow: Ekopros.

Gumilev, L. N. (1994). End and start again. Moscow: Tanais CI-DIC.

Hornung, E., Krauss, R., \& Warburton, D. A. (2006). Ancient Egyptian Chronology. Leiden-Boston-Köln: Brill.

Korostovtsev, M. A. (1963). Introduction to Egyptian philology. Moscow: Eastern Literature.

Kuzishchin, V. I. (Ed.). (1999). History of the Ancient East. Moscow: High School.

Ladynin, I. A. (2008). Ancient Egypt. In V. P. Budanova (Eds.), Ancient East (pp. 26-170). Moscow: Astrel: AST.

Ladynin, I. A., \& Nemirovsky, A. A. (1997). Annotation to work J. von Beckerath. Chronologie des pharaonischen Ägypten: Die Zeitbestimmung der ägyptischen Geschichte von der Vorzei bis 332 v. Chr., Mainz. Retrieved from http://www.egyptology.ru/annotations/Beckerath.pdf

Ladynin, I. A., Nemirovsky, A. A., Novikov, S. V., \& Nikishin, V. O. (2010). History of the Ancient World: East, Greece, Rome. Moscow: AST: WORD: Poligrafizdat.

Nemirovsky, A. A. (2008). Ancient Mesopotamia. In V. P. Budanova (Ed.), Ancient East (pp. 171-332). AST.

Saifullin, R. G. (2009). Historical process algorithmization. In Kuznetsov B. L. (Ed.). Economic Synergetics: Russia development strategy (pp. 106-126). Naberezhnye Chelny: INECA publishing house.

Saifullin, R. G. (2014). Polity and Population Quality Dynamics. Advances in Environmental Biology, 8(5), 1351-1356.

Sedov, A. V. (Ed.). (2004). The history of the ancient East. From early state formations to ancient empires. Moscow: Eastern Literature.

Stuchevsky, A. (1983). The "Persecution" of Amenhotep, "First priest" of Amun, and the incursion of the troops of Panehsi, "king's-son of Kush". Bulletin of ancient history, 1, 3-20.

Turchin, P. (2003). Historical Dynamics: Why States Rise and Fall. Princeton, NJ: "Princeton University Press".

\section{Copyrights}

Copyright for this article is retained by the author(s), with first publication rights granted to the journal.

This is an open-access article distributed under the terms and conditions of the Creative Commons Attribution license (http://creativecommons.org/licenses/by/3.0/). 